\title{
Reflections about the parallelism between experimental surgery and music
}

\author{
Saul Goldenberg* \\ *Founder of the Journal Acta Cirúrgica Brasileira and Brazilian Society for Development of Research in Surgery (SOBRADPEC)
}

\section{Introduction}

The present editorial was inspired by an article published by Nemeth 1 , in which he presented parallel ideas between microsurgery and music, motivating us to reflect about the relationship "experimental surgery and music". It is necessary to like both activities very much. Music has different effects on people, including the potential to harmonize the soul. Surgical practice has the same effect. The essential purpose of language is communication.

\section{Music}

Music is the art of communicating by means of sounds which originate from scores where there are small signs graphically represented in black together with printed or handwritten notation, showing the totality of all parts of a composition. It allows the reproduction and interpretation of the musical work. It is musical language.

\section{Experimental surgery}

The results of an experimental investigation also end up in a text reproduced in a piece of paper and represented by characters, using the rigidity of scientific writing. It communicates and allows other researchers to reproduce the proceedings. It is scientific language.

\section{Music \& Experimental surgery}

Both musical and scientific languages are universal. Music is the harmonious and expressive combination of sounds, based on some rules. In classical music, composition is methodical. It presents movements and independent sections:

the first movement, "alegro non troppo";

the second movement, "adágio";

the third movement, "scherzo";

the fourth movement, "allegro assai".
In experimental surgery, the sequence of investigation is also divided into parts, according to the Cartesian method. A published scientific article is necessarily divided into self-contained sections [as movements]:

\section{Introduction \\ Methods \\ Results \\ Discussion \\ Conclusion \\ References}

Both music and experimental surgery are subjected to standards and discipline. They rigorously fulfill norms and follow rules which are conventional. Nemeth1 emphasized the parallel between the one who composes and performs music and the one who practices microsurgery: talent, ability, vocation.

\section{A WAY OF ENRICHING OUR LIVES.}

Hands and eyes are used in both activities. Harmony and perfect tuning also have to be considered in musical work. In the case of experimental surgery, harmony exists among people with a certain common characteristic such as the members of the Brazilian Society for Development of Research in Surgery (Sobradpec), the Blue Community, where there are common ideals, peace, concordance and absence of conflicts. The blue color provides calm. For me Sobradpec have the sound of music. The Journal Acta Cirúrgica Brasileira is the lyrics. The orchestra is Sobradpec. Our partners are the players. Music gathers people, to whom a pleasant sensation is produced due to the adjustment and tuning of the instruments or voices. At the end comes the applause, the recognition of a job well done. Human values brought by music and experimental surgery. The best of us, which is capable of feeling and capturing everything, expressing it. Another parallel is the admiration and the respectful homage paid to the masters for their work both in music and experimental surgery. In music: Bach, Beethoven, Brahms, Chopin, Dvorak, Mozart, Mendelssohn, Schubert, Wagner and many others. In research [scientific method]: Aristotle, Socrates, Plato, 
Galileo, Bacon, Newton, Descartes, Claude Bernard, Ramón y Cajal and many others. There is certainly a difference between listening to music and making it. Music makes us feel better. It makes our everyday activities more pleasant and give us extra energy to work intellectually. In fact, music can be related to any cultural activity, medical or not, since the respective parallelism is established. To compose music and practice medicine is something extraordinary. It is the case of Norbert Németh1, who has been composing since he was 12 years old, which culminated in a musical work presented at the 7th Symposium of the International Society for Experimental Microsurgery, held on September 2004, at Debrecen-Hungary. Such work was edited in a CD: COMMEMORATIO - Fantasia per organo e canto, which also includes the composition MENDACIOUS ROMANCE - opera in three acts. In my opinion, a human being that composes, practices medicine and research must be special. In the X Symposium of SOBRADPEC, held at Cuiabá-Brazil, at the end of April 2007, we had the opportunity to know Németh, a modest and friendly person. Would this be the effect of music and research practice?

\section{MUSIC IS INNER LIFE AND WHO HAVE INNER LIFE WILL NEVER SUFFER FROM LONELINESS} (Artur da Távola2).

EXPERIMENTAL SURGERY IS INNER LIFE AND
THOSE WHO HAVE THAT INNER LIFE WILL
NEVER BE ISOLATED FROM THE WORLD, FOR
THEY WILL HAVE TO COMMUNICATE THE
RESULTS OF THEIR RESEARCH.

\section{References}

1. Németh N. Microsurgery and music: parallel ideas and philosophy? Microsurgery. 2007;27(3):155-7.

2. Artur da Távola. Quem tem medo da música clássica. TV Senado. http://www.arturdatavola.blogger.com.br em geral), a ciência (em suas diversas formas) e acrescento agora o esporte, são realmente as verdadeiras linguagens universais, imunes às diferenças de religião, crenças e raças. A música, a experimentação cirúrgica, e mesmo o esporte, têm - como foi apontado no editorial - paralelismos ou mesmo "parentescos" quando observamos que vivem de disciplina, método e rigores éticos, entre outras condições primárias. É interessante lembrar, por outro lado, a aproximação grande que sempre existiu entre a música e a cirurgia - que é ciência e arte, talvez arte e ciência. Alguns grandes cirurgiões eram músicos. Theodor Billroth tinha idéias radicais sobre a preparação dos cirurgiões na cirurgia experimental. Era músico, amigo de Johannes Brahms, tendo sido inclusive regente da Orquestra Sinfônica de Zurique.1 Alexandre Borodin, grande compositor e músico russo do século XIX, foi também médico e demonstrou em suas observações a relação do colesterol com as doenças cardíacas.2 Mais recentemente, Bernard Duhamel importantíssimo cirurgião pediatra com quem tive a honra de trabalhar - era músico e maestro titular de orquestra de câmara francesa. 3 Todos esses, experimentadores e músicos conhecidos, usaram certamente as condições fundamentais de ambos os campos cujo paralelismo agora o Prof. Saul Goldenberg, com sua experiência e sensibilidade, torna mais clara para todos. O mundo seria melhor se todos tivessem esta inspiração do nosso grande Professor.

\section{Referências}

1. McLaren N, Thorbeck RV. Little-known aspect of Theodor Billroth's work: his contribution to musical theory. World J Surg. 1997;21:569-71.

2. Filgueiras CAL. Entre a batuta e o tubo de ensaio: a carreira admirável de Alexandre Borodin. Quim Nova. 2002;6:1040-9.

3. Sylla P, Hardy MA. Bernard Duhamel: teacher and surgeon (1917-1996). Curr Surg. 2002;59:563-6.

\section{COMENTÁRIO:}

\section{Do Professor Paulo Juvêncio Gomes Tubino}

Professor Emérito da UnB

Presidente da Regional do Distrito Federal da SOBRADPEC

O editorial do Prof. Saul Goldenberg que trata do paralelismo entre a cirurgia experimental e a música é, a meu ver, um produto que poderia classificar como fisiológico da sensibilidade e da criatividade típicas do autor. É uma reflexão que enfatiza essas duas formas universais de comunicação. Arrisco-me a dizer que sempre defendi o ponto de vista de que a música (aliás, as artes 